\title{
DISTRIBUTION OF NON-FATAL ROAD TRAFFIC ACCIDENT CASES ADMITTED IN TERTIARY CARE CENTRE IN CENTRAL INDIA- A CROSS-SECTIONAL STUDY
}

\author{
Dadasaheb Dhage1, Yogesh Patil2, Mohan Khamgaonkar ${ }^{3}$
}

${ }_{1}^{1}$ Assistant Professor, Department of Community Medicine, GMC, Yevatmal, Maharashtra.

${ }^{2}$ Assistant Professor, Department of Community Medicine, R.C.S.M. GMC, Kolhapur, Maharashtra.

3Pro-Vice-Chancellor, MUHS, Nashik, Maharashtra.

\section{ABSTRACT}

\section{BACKGROUND}

In the background of high epidemiologic proportions of road traffic accidents and the fact that very few exploratory studies were reported from central India, the present study was undertaken to study distribution of non-fatal road traffic accident according to time, place and person.

Aims and Objectives- To study distribution of non-fatal road traffic accident cases admitted in tertiary care hospital according to time, place and person.

\section{MATERIALS AND METHODS}

Study Place- Tertiary care hospital from Central India. Study Type- Cross-sectional study. Study Period- One year (May 2014 to May 2015). Distribution of study subjects according to time, place and person was recorded in the proforma. Statistical analy sis was carried out with the help of software Epi Info version 7.2. Results were presented in percentages. Chi-square test was used as test of significance.

\section{RESULTS}

In temporal distribution, it was seen that $44 \%$ road traffic accident cases occurred in the evening and maximum road traffic accident cases occurred on weekends, i.e. on Saturdays (16.72\%) and on Sundays (17.39\%). 40.67\% of road traffic accident cases occurred in rainy season (June to September). In zone wise distribution of accidents which occurred inside city, $36.51 \%$ were seen in north zone. It was observed that in majority of accident cases, mode of transport was motorcycle (49.33\%). Males were significantly higher than females among the motorcycle occupants as compared to other modes of transport $\left(X^{2}=6.76, D F=1\right.$, $\mathrm{p}<0.01)$.

\section{CONCLUSION}

The present study clearly demonstrated that several factors such as rainy season, evening hours, weekends i.e. Saturday and Sunday, north zone of city was found to be more common in road traffic accidents. In majority of accident cases, mode of transport was motorcycle.

\section{KEYWORDS}

Distribution, Road Traffic Accidents, Time, Place, Person.

HOW TO CITE THIS ARTICLE: Dhage D, Patil Y, Khamgaonkar M. Distribution of non-fatal road traffic accident cases admitted in tertiary care centre in central India- a cross-sectional study. J. Evolution Med. Dent. Sci. 2018;7(14):1792-1795, D0I: $10.14260 /$ jemds $/ 2018 / 404$

\section{BACKGROUND}

"Every six seconds someone is killed or seriously injured on the world's roads. We simply cannot go on like this." Mr. David Cameron, Prime Minister of the United Kingdom of Great Britain and Northern Ireland.(1)

From high level ministerial gathering to expert symposia, press conferences, drawing competitions and cycling races, more than 400 events took place in all corners of world making official start of decade of action for road safety 20112020.(1)

'Financial or Other Competing Interest': None.

Submission 23-02-2018, Peer Review 20-03-2018,

Acceptance 26-03-2018, Published 02-04-2018.

Corresponding Author:

Dr. Yogesh Patil,

Flat No. 507, B Wing,

Sharda Vihar, Opposite Hockey Stadium,

Mangalwar Peth, Kolhapur-416012,

Maharashtra.

E-mail: drpatilyogesh1985@gmail.com

DOI: $10.14260 /$ jemds $/ 2018 / 404$

\section{(c) (i) $($ )}

Although, in the year 2012, Maharashtra had the highest number of registered vehicles in the country, but highest number of deaths due to road accidents during this year were reported in Tamilnadu $(16,175)$ followed by Uttar Pradesh $(15,109)$, Andhra Pradesh $(14,966)$ and Maharashtra $(13,936) .(2)$

Hence, in the background of high epidemiologic proportions of road traffic accidents and the fact that very few exploratory studies were reported from central India, the present study was undertaken to study distribution of nonfatal road traffic accident according to time, place and person.

\section{MATERIALS AND METHODS}

Study Place- Tertiary care hospital from Central India. Study type- A cross-sectional study. Study period- One year (May 2014 to May 2015). Approval from Institutional Ethics Committee was taken before initiation of study.

\section{Study Population}

Road traffic accident cases admitted in tertiary care hospital in city during the period of one year (May 2014 to May 2015) were included in the study with following inclusion and exclusion criteria. 


\section{Inclusion Criteria}

1. Road traffic accident cases admitted in hospital.

2. Road traffic accident cases who were conscious and cooperative.

3. Road traffic accident cases who had given written informed consent.

\section{Exclusion Criteria}

1. Road traffic accident cases who were admitted in surgical intensive care unit (SICU) of hospital.

2. Road traffic accident cases who took discharge against medical advice (DAMA).

3. Road traffic accident cases brought dead in casualty department.

4. Road traffic accident cases who were unable to participate in the study due to impaired health status.

Distribution of road traffic accident cases reported to casualty department of tertiary care hospital was recorded on each day to identify accident cases admitted in hospital on that day. During data collection of one year, distribution of road traffic accident cases reported in casualty was as follows.

\section{Statistical Analysis}

Statistical analysis was carried out with the help of software Epi Info version 7.2. Results were presented in percentages and numbers. Chi-square test was used as test of significance. $P$ value less than 0.05 was considered for level of significance.

\begin{tabular}{|c|c|c|}
\hline $\begin{array}{c}\text { Distribution of Road Traffic Accident } \\
\text { Cases Reported at Casualty }\end{array}$ & Number & $\mathbf{\%}$ \\
\hline Managed on OPD basis & 1877 & 70.86 \\
\hline Discharged against medical advice & 196 & 7.40 \\
\hline Admitted in ward & 481 & 18.16 \\
\hline Admitted in Surgical intensive care unit & 27 & 1.02 \\
\hline Brought dead & 68 & 2.56 \\
\hline Total & $\mathbf{2 6 4 9}$ & $\mathbf{1 0 0}$ \\
\hline
\end{tabular}

Table 1. Distribution of Road Traffic Accident cases reported to Casualty

There were total 481 road traffic accident cases admitted in hospital during the period of one year. Distribution of these 481 cases admitted in hospital was as follows: Out of these 481 road traffic accident cases of 300 were interviewed and examined for the study.

\begin{tabular}{|c|c|c|}
\hline $\begin{array}{l}\text { Distribution of Admitted Road } \\
\text { Traffic Accident Cases }\end{array}$ & Number & Percentage \\
\hline Number of cases interviewed & 300 & 62.37 \\
\hline $\begin{array}{l}\text { Were not able to participate in the } \\
\text { study }\end{array}$ & 131 & 27.13 \\
\hline Consent not given & 50 & 10.50 \\
\hline Total & 481 & 100 \\
\hline \multicolumn{3}{|c|}{$\begin{array}{c}\text { Table 2. Distribution of } 481 \text { Road Traffic Accident cases } \\
\text { admitted in Hospital }\end{array}$} \\
\hline
\end{tabular}

\section{Study Methodology}

A pre-tested proforma was used for collecting relevant information from study subjects by direct interview method. Information regarding distribution of road traffic accidents according to time, place and person was recorded in the proforma.

\section{RESULTS}

The present cross-sectional study was carried out in a tertiary care hospital in central India. Three hundred road traffic accident cases were studied in detail with regard to their distribution according to time, place and person.

\begin{tabular}{|c|c|c|c|c|c|c|c|c|}
\hline \multirow{3}{*}{$\begin{array}{c}\text { Time of } \\
\text { Occurrence } \\
\text { of the } \\
\text { Accidents }\end{array}$} & \multicolumn{8}{|c|}{ Category of Study Subjects } \\
\hline & \multicolumn{2}{|c|}{ Drivers } & \multicolumn{2}{|c|}{ Passengers } & \multicolumn{2}{|c|}{ Pedestrians } & \multicolumn{2}{|c|}{ Total } \\
\hline & No. & $\%$ & No. & $\%$ & No. & $\%$ & No. & $\%$ \\
\hline $\begin{array}{c}\text { Night } \\
(12 \text { midnight } \\
\text { to } 5: 59 \mathrm{am})\end{array}$ & 5 & 3.94 & 9 & 10 & 2 & 2.41 & 16 & 5.33 \\
\hline $\begin{array}{c}\text { Morning } \\
\text { (6 am to } \\
11: 59 \mathrm{am})\end{array}$ & 20 & 15.74 & 14 & 15.56 & 16 & 19.28 & 50 & 16.67 \\
\hline $\begin{array}{l}\text { After noon } \\
\text { (12 noon to } \\
5: 59 \mathrm{pm})\end{array}$ & 51 & 40.16 & 25 & 27.77 & 26 & 31.33 & 102 & 34 \\
\hline $\begin{array}{c}\text { Evening } \\
\text { (6 pm to } \\
11: 59 \mathrm{pm})\end{array}$ & 51 & 40.16 & 42 & 46.67 & 39 & 46.98 & 132 & 44 \\
\hline Total & 127 & 100 & 90 & 100 & 83 & 100 & 300 & 100 \\
\hline
\end{tabular}

Above table shows that maximum road traffic accident cases met with accident at the evening was 132 (44\%). This was followed by afternoon of 102 (34\%), morning of 50 $(16.67 \%)$ and night of 16 (5.33\%).

\begin{tabular}{|c|c|c|c|c|c|c|c|c|}
\hline \multirow{3}{*}{$\begin{array}{c}\text { Day of } \\
\text { Accident }\end{array}$} & \multicolumn{8}{|c|}{ Category of Subjects } \\
\hline & \multicolumn{2}{|c|}{ Drivers } & \multicolumn{4}{|c|}{ PassengersPedestrians } & \multicolumn{2}{|c|}{ Total } \\
\hline & No. & $\%$ & No. & $\%$ & No. & $\%$ & No & $\%$ \\
\hline Monday & 20 & 15.75 & 14 & 15.56 & 11 & 13.25 & 45 & 15.05 \\
\hline Tues & 19 & 14.95 & 11 & 12.23 & 13 & 5.66 & 43 & 14.38 \\
\hline Wedne & 21 & 16.54 & 13 & 14.44 & 10 & 12.05 & 44 & 14.72 \\
\hline Thur & 13 & 10.24 & 10 & 11.11 & 04 & 4.82 & 27 & 9.03 \\
\hline Frid & 12 & 9.45 & 12 & 13.33 & 14 & 16.87 & 38 & 12.71 \\
\hline Satur & 20 & 15.75 & 12 & 13.33 & 19 & 22.89 & 51 & 16.72 \\
\hline Sunday & 22 & 17.32 & 18 & 20 & 12 & 14.46 & 52 & 17.39 \\
\hline Total & 127 & 100 & 90 & 100 & 83 & 100 & 300 & 100 \\
\hline & & & & & & & & \\
\hline
\end{tabular}

Table No. 4 shows that maximum road traffic accident cases were seen on weekends, i.e. on Sunday 52 (17.39\%), followed by Saturday 51 (16.72\%).

\begin{tabular}{|c|c|c|c|c|c|c|c|c|}
\hline \multirow{2}{*}{$\begin{array}{c}\text { Season of } \\
\text { the Year }\end{array}$} & \multicolumn{7}{|c|}{ Category of Study Subject } \\
\cline { 2 - 9 } & Do. & $\mathbf{0}$ & No. & $\%$ & No. & $\%$ & No. & $\%$ \\
\hline $\begin{array}{c}\text { February to } \\
\text { May } \\
\text { (Summer) }\end{array}$ & 43 & 33.86 & 33 & 36.67 & 28 & 33.73 & 104 & 34.67 \\
\hline $\begin{array}{c}\text { June to } \\
\text { September } \\
\text { (Rainy) }\end{array}$ & 47 & 37.01 & 44 & 48.89 & 31 & 37.35 & 122 & 40.67 \\
\hline $\begin{array}{c}\text { October to } \\
\text { January } \\
\text { (Winter) }\end{array}$ & 37 & 29.13 & 13 & 14.44 & 24 & 28.92 & 74 & 24.66 \\
\hline Total & $\mathbf{1 2 7}$ & $\mathbf{1 0 0}$ & $\mathbf{9 0}$ & $\mathbf{1 0 0}$ & $\mathbf{8 3}$ & $\mathbf{1 0 0}$ & $\mathbf{3 0 0}$ & $\mathbf{1 0 0}$ \\
\hline Table 5. Distribution of Study Subjects according to \\
Seasons of the Year \\
\hline
\end{tabular}

Table No. 5 shows maximum number of road traffic accident cases occurred in rainy season (June to September) 
122 (40.67\%) followed by summer season (February to May) $104(34.67 \%)$ and winter season (October to January) 74 (24.66\%).

\begin{tabular}{|c|c|c|}
\hline City Zones & Number & Percentage \\
\hline East & 20 & 6.67 \\
\hline West & 36 & 12.00 \\
\hline North & 65 & 21.67 \\
\hline South & 06 & 2.00 \\
\hline Central & 41 & 13.67 \\
\hline Southwest & 10 & 3.33 \\
\hline Outside city & 76 & 25.33 \\
\hline Outside district & 46 & 15.33 \\
\hline Total & 300 & 100 \\
\hline \multicolumn{3}{|c|}{$\begin{array}{l}\text { Table 6. Distribution of Study Subjects } \\
\text { according to Zones of the City }\end{array}$} \\
\hline
\end{tabular}

*These zones are according to parliament constituency zones of the city.

Table No. 6 shows that out of total accidents which occurred inside city, maximum were seen in north zone i.e. 65 (36.51\%) followed by central zone 41 (23.03\%), west zone $36(20.22 \%)$, east zone $20(11.24 \%)$, south-west zone 10 (5.63\%), and south zone 6 (3.37\%).

\begin{tabular}{|c|c|c|c|c|c|c|}
\hline \multirow{2}{*}{$\begin{array}{c}\text { Mode of Transport } \\
\text { of Study Subjects }\end{array}$} & \multicolumn{2}{|c|}{ Male } & \multicolumn{2}{c|}{ Female } & \multicolumn{2}{c|}{ Total } \\
\cline { 2 - 7 } & No. & $\mathbf{\%}$ & No. & $\mathbf{\%}$ & No. & \% \\
\hline Pedestrian & 62 & 24.51 & 21 & 45.68 & 83 & 26.67 \\
\hline Pedal-Cyclist & 29 & 11.46 & 5 & 10.64 & 34 & 12.33 \\
\hline Motorcycle & 133 & 52.57 & 15 & 31.92 & 148 & 49.33 \\
\hline Other & 29 & 11.46 & 6 & 11.76 & 35 & 11.67 \\
\hline Total & $\mathbf{2 5 3}$ & $\mathbf{1 0 0}$ & $\mathbf{5 3}$ & $\mathbf{1 0 0}$ & $\mathbf{3 0 0}$ & $\mathbf{1 0 0}$ \\
\hline
\end{tabular}

Table 7 shows that among majority of accident cases mode of transport was motorcycle 148 (49.33\%) followed by pedestrian 83 (26.67\%), other vehicles 35 (11.67\%) and pedal-cyclist $34(11.33 \%)$. Males having motorcycle 133 $(52.57 \%)$ as mode of transport are significantly higher as compared to males using rest of the modes of transport $\left(\mathrm{X}^{2}=6.76, \mathrm{DF}=1, \mathrm{p}<0.01\right)$.

\section{DISCUSSION}

The present study showed that maximum road traffic accident cases met with accident in the evening $(6 \mathrm{pm}$ to $11: 59 \mathrm{pm})(44 \%)$. This is followed by afternoon (12 noon to $5: 59 \mathrm{pm}$ ) (34\%), morning ( $6 \mathrm{am}$ to $11: 59 \mathrm{am})(16.67 \%)$ and night (12 midnight to 5:59 am) (5.33\%). This may be attributed to decreased visibility and maximum traffic congestion in the evening hours. Lot of variation was observed in distribution of accidents according to time in a number of studies reviewed. Some studies showed finding similar to present study. E Ravikiran et al (2003)(3) found that maximum $(33.5 \%)$ of the accidents occurred in the evening and the minimum $13.0 \%$ occurred in the night. Ghosh SK et al $(2004)^{(4)}$ observed that maximum number of accidents occurred during $6 \mathrm{pm}$ to $10 \mathrm{pm}$ and may be attributed to the combined rush in evening along with poor lighting. Singh A et al (2011)(5) observed that most of the accidents (40.15\%) occurred in the evening ( $6 \mathrm{pm}-12$ midnight).

The present study showed that maximum road traffic accident cases were seen on weekends, i.e. on Sunday (17.39\%) followed by Saturday (16.72\%). As weekends are holidays this may be attributed to more congestion on roads in weekends. There were some studies which showed similar results. Jha $\mathrm{N}$ et al (2004)(6) observed that the highest number of accidents $(17.1 \%)$ took place on Sundays. Jha $S$ et al (2010)(7) found that most of the accidents irrespective of the cause occurred on Saturday (24.6\%). Aggarwal A (2012)(8) found that more than half of accidents had occurred on Saturday and Sunday.

In the present study, it was observed that maximum number of road traffic accident cases occurred in rainy season (June to September) (40.67\%) followed by summer season (February to May) (34.67\%) and winter season (October to January) (24.66\%). There was variation seen in individual studies in distribution of accident cases according to months of year. Also variation was observed in seasons of the year in different regions of country. There were some studies with similar results. E Ravikiran et al (2003)(3) observed that the maximum number of accidents (48.5\%) occurred in rainy season followed by $33.5 \%$ in winter and the least $18.0 \%$ in summer. Pathak MSM et al (2013) observed that maximum cases (46.7\%) took place during monsoons (July - October).

The present study showed that maximum accident cases i.e. $59.33 \%$ occurred inside the city, while $40.67 \%$ accident cases occurred outside the city. Out of total accidents which occurred inside city, maximum were seen in north zone (36.51\%) followed by central zone (23.03\%), west zone (20.22\%), east zone (11.24\%), south-west zone 10 (5.63\%) and south zone $(3.37 \%)$. Maximum cases were seen in north zone of city and this may be attributed to the fact that interstate highway which always has congestion passes through this zone. Also, the north zone was near to the tertiary care hospital in which study was carried out.

The present study showed that among majority of accident cases, mode of transport was motorcycle (49.33\%) followed by pedestrian (26.67\%), other vehicles $(11.67 \%)$ and pedal-cyclist (11.33\%). Males having motorcycle $(52.57 \%)$ as mode of transport were significantly higher as compared to males using rest of the modes of transport. Twowheelers involved in road accidents were $49.33 \%$ and this large proportion may be attributed to the fact that two wheelers have to share scarce road space with motorised vehicles of different engine power and speed resulting in serious conflicts within traffic flows. Similar findings were given by some studies. Odero W (1997) ${ }^{(9)}$ found that pedal cyclists and motorcyclists killed ranked first in India and Surinam. Gururaj G (2008)(10) found that vast majority of those killed and injured were pedestrians, motorcycle riders and bicyclists. WHO Global Report on Road Safety (2009)(11) showed that pedestrians, cyclists, motorcycle riders and their passengers accounted for $46 \%$ of global road traffic deaths. Mohan D (2009) ${ }^{(12)}$ published a paper on road accidents in India and mentioned that vulnerable road users (pedestrians, bicyclists and motorised two-wheeler riders) accounted for $84 \%$ of deaths in Delhi and $67 \%$ on highways. Kelkar A (2011)(13) mentioned that the vulnerable road users such as the pedestrians, users of non-motorised transport, cyclists and users of two wheeled motorised vehicles accounted for a large majority of the accident victims in India. Chauhan A $(2014)^{(14)}$ found that a high proportion of patients of road traffic injuries were either motorised two wheelers driver i.e. 
$43.1 \%$ or pillion riders i.e. $15.4 \%$. Pedestrians were $14.2 \%$ and Pedal cyclists were $4.9 \%$.

\section{CONCLUSION}

The present study clearly demonstrated that several factors such as rainy season, evening hours, weekends i.e. Saturday and Sunday, north zone of city was found to be more common in road traffic accidents. In majority of accident cases, mode of transport was motorcycle.

\section{REFERENCES}

[1] WHO. Decade of action for Road Safety 2011-2020 Global Launch. 2011.

[2] Road Accidents in India 2013. Government of India, Ministry of Road Transport \& Highways and Transport Research Wing, New Delhi. 2013.

[3] Kiran ER, Saralaya KM, Vijaya K. Prospective study on road traffic accidents. J Punjab Acad Forensic Med Toxicol 2004;4:12-6.

[4] Ghosh SK, Parida M, Uraon JK. Traffic Accident Analysis for Dehradun City Using GIS. ITPI J 2004;1(3):40-54.

[5] Singh A, Bhardwaj A, Pathak R, et al. An epidemiological study of road traffic accident cases at tertiary hospital in rural Haryana. Indian J Community Health 2011;23(2):53-6.
[6] Jha N, Srinivasa DK, Roy G, et al. Epidemiological study of road traffic accident cases: a study from south India. Indian J Community Med 2004;29(1):20-4.

[7] Jha S, Yadav BN, Karn A, et al. Epidemiological study of fatal head injury in road traffic accident cases : a study from BPKIHS, Dharan. Heal Renaiss 2010;8(2):97-101.

[8] Aggarwal A, Kaur S, Dhillon MS. Sociodemographic profile of road traffic accident victims admitted at emergency surgical OPD of a tertiary care hospital. J Postgrad Med Educ \& Res 2012;46(1):15-8.

[9] Odero W, Garner P, Zwi A. Road traffic injuries in developing countries: a comprehensive review of epidemiological studies. Trop Med Int Heal 1997;2(5):445-60.

[10] Gururaj G. Road traffic deaths, injuries and disabilities in India: current scenario. Natl Med J India 2008;21(1):14-20.

[11] World Health Organization. Global status report on road safety. Injury Prevention. 2009.

[12] Mohan D. Road Accidents in India. IATSS Research. International Association of Traffic and Safety Sciences 2009.

[13] Kelkar A. Epidemiology of road traffic accidents in India: a review of literature. 2011.

[14] Chauhan A, Ahmed N, Singh JV, et al. Epidemiology of road traffic injuries in a tertiary care centre of Lucknow. Indian J Community Health 2014;26(2): 181-6. 